\title{
EFFECT OF DUMYATI DUCK BREEDERS AGE ON PRODUCTIVE PERFORMANCE, EGG TRAITS AND THEIR OFFSPRING DUCKLING PERFORMANCE
}

\author{
Mona, M., El-Ghareeb ${ }^{1,}$ Nabil, Abu -Heakal, S.A ${ }^{1}$. Yousef, Y., Seady ${ }^{1}$. and A. M. El-Shhat ${ }^{2}$ \\ ${ }^{1}$ Department of Physiology, Faculty of Veterinary Medicine, Mansoura University. \\ ${ }^{2}$ Anim. Prod. Res. Institute, Agric. Res. Center, Ministry of Agric; Dokki, Giza, Egypt.
}

\begin{abstract}
This study was conducted to investigate how ducks age (Dumyati strain) could affect on some productive traits, egg quality and performance of their offspring. Egg number, egg weight egg mass, Egg production \%, feed consumption and feed conversion to egg was investigated during three periods at (24-32)wk, (32-40) wk and (40-48) wk. While 30 eggs were collected for determination egg quality at 4 different ages $(24,32,40,48)$ wk old including (egg weight, egg shape index \% (ESI), shell \% and thickness, albumin \%, Haugh unit $(\mathrm{HU})$,yolk \%, yolk index and yolk color and shell \% and thickness, while a total of 2016 eggs were set in the incubator (504 egg /age) at the same intervals to determine egg hatchability traits. After complete hatching, (30) duckling-one day old-from each age weighed (initial body weight) and raised for 10 wk old through this period body weight $(B W)$, body weight gain $(B W G)$, feed consumption (F.C) and feed conversion ratio (FCR) were recorded bi-weekly. The Results of this investigation revealed that, egg production \% and egg number significantly decreased with age, while egg weight significantly increased .but egg mass and FCR during 3 different periods didn't show any significant difference. Some egg traits (egg weight, ESI\%, yolk \% and shell thickness) were significantly increased with advancing ducks age. However, albumin proportion significantly decreased as the productive season progress, but shell \% didn't show any significant difference between different ages. $H U$ and yolk index show deterioration with age. Fertility \% of eggs significantly increased with age advancing, While early mortality \% was significantly higher at the begging of laying season (24 wk old), also total embryonic mortality\% showed significant increase in eggs from young ducks breeder, however hatchability of total egg $\%$ didn't show any significant difference. Ducklings weight at hatch showed a significant increase with age, but this did not reflect on final body weight or BWG, which significantly decreased with age. Older breeder (48) wk old showed the lowest F.C and 40 wk old breeders had the lowest FCR. No-doubt that age of ducks in this study had a clear effect on some productive traits, egg traits and somewhat performance of offspring. Although of that we can't ignore environmental temperature changes with aging of ducks flock.

Key words: Dumyati ducks, Breeder age, productive performance, egg quality, hatchability and growth performance of offspring.
\end{abstract}

\section{INTRODUCTION}

Duck production plays vital roles in the economy of rural community in Egypt (Awad, 2013). They provide cash income and create employment opportunity for rural people (Khan et al., 1999). They can be raised cheaper than broiler especially when its market is well organized (Singh, 2001). There are several factors affecting ducks egg quality and hatchability traits, subsequently developing embryo and may be the performance of their young duckling, among these factors breeder age and its body weight that have considerable influence on both productive and reproductive traits (Gallo et al., 2005). With advancing breeder age, egg production rate decreased (Tumova and Gouus, 2012), and egg number 
also decreased (Rayan et al., (2013) .While egg weight, egg volume and surface area were increased with increasing of the hen's age ( ElSheikh et al., 2014) .

Tona et al., (2004) reported that the weight of $18 \mathrm{~d}$ old embryo increased with parental age .Eggs from older hen breeder characterized by higher yolk weight and lower white weight on average when compared with hen at the onset of egg laying, in addition to quality of egg yolk deteriorates as the reproductive season of broiler breeder progress (Pirsaraei et al., (2011). Moreover, albumin characteristics including (albumin index and Haugh unit) and egg shell traits including (weight and thickness) deteriorated as hen aged (Akyrek and Okur, 2009). Fertility and hatchability percentages of egg produced from the younger flock age were higher than those from the older ones, while embryonic mortality percent not affected by flock age (Awad and Abd El-Halim, 2014).

Changes in egg quality with advancing age, May reflected on their offspring development and performance. As one-day-old broiler, chick weights were higher for chicks from old breeder 45 wk old than young breeder 35 wk old until 14-day-old, However percentage of high quality chicks from $45 \mathrm{wk}$ old were lower than 35wk old (Tona et al., 2004). In contrast, Ulmer- Franco, et al., (2012) reported lower final body weight of newly hatched chick from young breeder 29 wks old.

Several studies demonstrated influence of broiler and turkey breeder age on egg quality and offspring performance, but few studies have support such possibilities in ducks (Braun et al., 2002). Hence, this study was carried out on local Egyptian duck strain (Dumyati duck) to study this impact.

\section{MATERIALS AND METHODS}

\section{Ducks:}

A total number of one hundred and sixty eight Dumyati ducks of (144 females and 24 drakes) were monitored from the El-Serw Waterfowls Research Station, Damietta, Animal Production Research Institute, Agricultural Research Center, Egypt during the period from October, 2016 to August, 2017. Ducks were leg banded, individually weighed and randomly divided into six equal groups, each pen contained 28 ducks ( 24 females and 4 drakes) were exposed to $16 \mathrm{hrs}$ of light daily. They were reared under the same managerial and hygienic conditions. Fresh water and ration were offered ad-libitum. The ration was formulated to meet ducks requirements according to Feed composition tables for animal and poultry feedstuffs used in Egypt, (2001) are shown in (Table1).

\section{Productive traits measurements:}

II.1.Egg number and egg weight (EW) were recorded daily

II.2. Egg mass was calculated per duck from the following formula:

$\mathrm{EM}=\underline{\text { Total egg mass per pen (egg numberX egg weight) }}$ Number of ducks at pen

\section{II.3. Egg production (\%) was calculated as}

Egg production rate $=\frac{\text { Number of egg produced }}{\text { Number of live ducks }}$ X100

II.4.Feed consumption (FC) of each pen was calculated through division of total FC by number of live ducks.

II.5. Feed conversion ratio (FCR) for egg production was calculated as follows:

$$
\mathrm{FCR}=\frac{\text { Feed kg }}{\text { Egg kg }}
$$


All these parameters were determined during 3 periods (24-32) wks, (32-40) wk and (40-48) wk according to (Rayan et al., 2013).

\section{Egg quality measurements:}

30 eggs were collected from each age at (24, 32, 40 and 48) weeks for determination external and internal quality of fresh eggs

III.1. In the same day, eggs were numbered and weighed individually using sensitive weighing scale electronic balance (0.01 accuracy).

III.2. Length and width of eggs was measured using digital vernir caliper to calculate egg shape index using the formula of Carter, (1968):

Egg shape index $(\%)=\frac{\text { Egg width }}{\text { Egg length }} \times 100$

Then, eggs were broken on Petri dish $(15 \mathrm{c} . \mathrm{m})$ and the following parameters were determined

III.3.Albumin percentage was determined as albumin was weighed and calculated as percentages of egg weight and albumin height measured by digital vernier caliper for calculation of Haugh unit according to (Haugh, 1937) from the following formula:

$$
\mathrm{HU}=100 \log \left(\mathrm{AH}+7.57-1.7 \mathrm{xWW}^{\mathbf{0 . 3 7}}\right)
$$

Where: $\mathrm{AH}=$ albumin height $(\mathrm{mm}), \mathrm{EW}=$ egg weight $(\mathrm{g})$.

III.4. Yolk percentage was determined as yolk was weighed and calculated as percentages of egg weight while yolk height and diameter was measured by digital vernier caliper to determine yolk index (\%) according to Abu-tabeakh, (2011) from the following formula:

$$
\text { Yolk index }(\%)=\frac{\text { Yolk height }}{\text { Yolk diameter }} \times 100
$$

III.5. Egg yolk color was determined by using La-Roche scale.

III.6.The weights of shell was recorded and calculated as percentages of egg weight.

III.7.Shell thickness was measured in three different parts (sharp, blunt and equatorial) by micrometer (Tyler, 1961).

\section{IV.Egg fertility and hatchability percentages:}

504 eggs from each age $(24,32,40$ and 48 weeks) were collected, numbered, washed, fumigated, and individually weighed. Eggs were set in an electric forced draft local industrial multistage incubator system to determine both fertility and hatchability percentages. Fertility percentage and early embryonic mortality percentage were determined in the $10^{\text {th }}$ day of incubation according to (Othman et al., 2014). On day 24 of incubation late embryonic mortality percentage were determined then; eggs were transferred to a hatcher. On day 28 of incubation the embryo piped but unhatched, total mortality and hatched duckling's percentage were recorded according to (Malik et al., 2015).Ducklings weight at hatch was recorded for each age.

\section{Young ducklings performance:}

The young ducklings were transported to grow out facility and give access to water and feed ad libitum. The ration offered to young duckling was formulated according to Feed composition tables for animal and poultry feedstuffs used in Egypt (2001), (Table 2). 30 ducklings were marked by leg marks individually and divided into three replicate raised on concrete floors with five centimeters 
thick wood shaving as bedding. Initial body weight was recorded, then body weight (BWT), body weight gain (BWG), feed consumption (FC) and feed conversion ratio (FCR) were recorded bi- weekly.

\section{VI .Statistical analysis:}

Data obtained were statistically analyzed for variance using the General linear Model of SAS, (2002). The used model was: $Y_{i j}=\mu+T_{i}$ $+\mathrm{e}_{\mathrm{ij}}$, Where: $\mathrm{Y}_{\mathrm{ij}}=$ an observation, $\mu=$ Overall mean, $\mathrm{T}_{\mathrm{i}}=$ Effect of duck breeder age $(\mathrm{i}=1,2,3$ and 4 ), and $\mathrm{e}_{\mathrm{ij}}=$ Random error. Means were tested for significant difference by using Duncan's multiple range test (Duncan, 1955).

Table 1: Composition and calculated analysis of ration offered to the local Domiaty ducks throughout the experimental periods ( $24 \mathrm{wk}$ to $48 \mathrm{wk}$ )

\begin{tabular}{|l|c|}
\hline \multicolumn{1}{|c|}{ Ingredients \% } & Layer (24-48) weeks of age \\
\hline Yellow corn & 62.25 \\
\hline Soybean meal (44\%) & 19.75 \\
\hline Corn gluten meal (60\%) & 4.27 \\
\hline Wheat bran & 3.00 \\
\hline Limestone & 8.61 \\
\hline Di-calcium phosphate & 1.39 \\
\hline Vit.\& Min. Premix ${ }^{1}$ & 0.30 \\
\hline Salt (NaCl) & 0.37 \\
\hline Dl-methionine (97\%) & 0.06 \\
\hline Total & 100.00 \\
\hline Calculated analysis ${ }^{2}:$ & \\
\hline Crude protein (\%) & 16.53 \\
\hline ME (kcal/ kg) & 2756 \\
\hline Calcium (\%) & 3.51 \\
\hline Av. Phosphorus (\%) & 0.38 \\
\hline Methionine (\%) & 0.43 \\
\hline
\end{tabular}

${ }^{1}$-Each $3 \mathrm{~kg}$ of the Vit. and Min. premix contains: Vitamin A, $10000000 \mathrm{IU}$, Vit. D $2000000 \mathrm{IU}$, Vit E $10 \mathrm{~g}$, Vit. K 2 g, Thiamin 1 g, Riboflavin 5 g, Pyridoxine 1.5 g, Niacin 30 g, Vit. B12 $10 \mathrm{mg}$, Pantothenic acid 10 g, Folic acid 1.5 g, Biotin $50 \mathrm{mg}$, Choline chloride $250 \mathrm{~g}$, Manganese $60 \mathrm{~g}$, Zinc $50 \mathrm{~g}$, Iron $30 \mathrm{~g}$, Copper $10 \mathrm{~g}$, Iodine $1 \mathrm{~g}$, Selenium $0.10 \mathrm{~g}$, Cobalt $0.10 \mathrm{~g}$.andcarrierCaCo3to3000g. ${ }^{2}$ - According to Feed composition tables for animal and poultry feedstuffs used in Egypt (2001). 
Table (2): Composition and calculated analysis of the ration offered to the local Domiaty ducklings throughout the raising period (10wk).

\begin{tabular}{|l|c|c|c|}
\hline \multicolumn{1}{|c|}{ Ingredients \% } & Starter(0-4) wks & Grower (4-8) wks & Finisher (8-10) wks \\
\hline Yellow corn & 65.20 & 70.90 & 72.70 \\
\hline Soybean meal (44\%) & 21.50 & 18.60 & 17.30 \\
\hline Corn gluten meal (60\%) & 9.25 & 5.30 & 4.15 \\
\hline Wheat bran & 0.00 & 1.15 & 2.00 \\
\hline Limestone & 1.30 & 1.40 & 1.30 \\
\hline Di-calcium phosphate & 1.90 & 1.80 & 1.70 \\
\hline Vit.\& Min. Premix ${ }^{1}$ & 0.40 & 0.40 & 0.40 \\
\hline Salt (NaCl) & 0.35 & 0.35 & 0.35 \\
\hline Dl-methionine (97\%) & 0.10 & 0.10 & 0.10 \\
\hline Total & 100.00 & 100.00 & 100.00 \\
\hline Calculated analysis ${ }^{2}:$ & & & 16.00 \\
\hline Crude protein (\%) & 20.03 & 17.00 & 3000 \\
\hline ME (kcal/ kg) & 3005 & 3001 & 0.96 \\
\hline Calcium (\%) & 1.02 & 1.03 & 0.44 \\
\hline Av. Phosphorus (\%) & 0.48 & 0.46 & 0.43 \\
\hline Meth. (\%) & 0.52 & 0.45 & \\
\hline
\end{tabular}

'-Each $3 \mathrm{~kg}$ of the Vit. and Min. premix contains: Vitamin A, 10000000 IU, Vit. D 2000000 IU, Vit E 10 g, Vit. K 2 g, Thiamin $1 \mathrm{~g}$, Riboflavin $5 \mathrm{~g}$, Pyridoxine $1.5 \mathrm{~g}$, Niacin $30 \mathrm{~g}$, Vit. B12 $10 \mathrm{mg}$, Pantothenic acid $10 \mathrm{~g}$, Folic acid $1.5 \mathrm{~g}$, Biotin $50 \mathrm{mg}$, Choline chloride $250 \mathrm{~g}$, Manganese $60 \mathrm{~g}$, Zinc $50 \mathrm{~g}$, Iron $30 \mathrm{~g}$, Copper $10 \mathrm{~g}$, Iodine 1g, Selenium 0.10 $\mathrm{g}, \mathrm{C}$ obalt $0.10 \mathrm{~g}$.andcarrierCaCo3to3000g.

${ }^{2}$ - Accor ding to Feed composition tables for animal and poultry feedstuffs used in Egypt (2001).

Table 3: Relation between duck age and egg production traits:

\begin{tabular}{|l|c|c|c|c|}
\hline & $\mathbf{2 4 - 3 2} \mathbf{~ w k}$ & $\mathbf{3 2 - 4 0} \mathbf{~ w k}$ & $\mathbf{4 0 - 4 8 w k}$ & Significance \\
\hline Egg number & $34.6 \pm 1.0^{\mathrm{a}}$ & $31.7 \pm 1.0^{\mathrm{ab}}$ & $30.1^{\mathrm{b}} \pm 1.0 \mathrm{~b}$ & $*$ \\
\hline Egg weight $(\mathrm{g})$ & $59.7 \pm 1.2^{\mathrm{c}}$ & $66.3 \pm 1.20^{\mathrm{b}}$ & $71.4^{\mathrm{a}} \pm 1.2 \mathrm{a}$ & $* *$ \\
\hline Egg mass $(\mathrm{g})$ & $2067.8 \pm 99.2$ & $2101.1 \pm 99.2$ & $2149.4 \pm 99.2$ & $\mathbf{N S}$ \\
\hline Egg production\% & $61.8 \pm 1.7^{\mathrm{a}}$ & $56.6 \pm 1.7^{\mathrm{ab}}$ & $53.7^{\mathrm{b}} \pm 1.7^{\mathrm{b}}$ & $*$ \\
\hline Feed consumption $(\mathrm{g})$ & $8926.0 \pm 68.2^{\mathrm{b}}$ & $9246.0 \pm 68.2^{\mathrm{a}}$ & $9479.0^{\mathrm{a}} \pm 68.2^{\mathrm{a}}$ & $* *$ \\
\hline Feed conversion ratio & $4.30 \pm 0.20$ & $4.40 \pm .20$ & $4.40 \pm .20$ & $\mathbf{N S}$ \\
\hline
\end{tabular}

Means in the same row with different letters are significantly different $(\mathrm{p} \leq 0.05)$ where , NS .Non-significant - * $(\mathrm{p} \leq 0.05)-* *(\mathrm{p} \leq 0.01)$. 
Table 4: Relation between duck age and egg traits at 4 different ages

\begin{tabular}{|l|c|c|c|c|c|}
\hline & At 24 wk & At 32 wk & At 40 wk & AT 48 wk & Significance \\
\hline Egg weight $(\mathrm{g})$ & $57.5 \pm 0.81^{\mathrm{c}}$ & $69.9 \pm 1.35^{\mathrm{b}}$ & $75.2 \pm 0.84^{\mathrm{a}}$ & $75.7 \pm 0.94^{\mathrm{a}}$ & $* * *$ \\
\hline ESI \% & $71.9 \pm 0.66^{\mathrm{c}}$ & $74.6 \pm 0.5^{\mathrm{b}}$ & $75.80 \pm 0.36^{\mathrm{b}}$ & $78.3 \pm 0.70^{\mathrm{a}}$ & $* * *$ \\
\hline Albumin \% & $58.56 \pm 0.47^{\mathrm{a}}$ & $57.80 \pm 0.75^{\mathrm{ab}}$ & $55.99 \pm 0.63^{\mathrm{c}}$ & $56.62 \pm 0.36^{\mathrm{bc}}$ & $*$ \\
\hline HU\% & $87.43 \pm 0.86^{\mathrm{a}}$ & $85.47 \pm 1.11^{\mathrm{a}}$ & $85.08 \pm 1.02^{\mathrm{a}}$ & $81.79 \pm 1.33^{\mathrm{b}}$ & $* *$ \\
\hline Yolk \% & $31.77 \pm 0.5^{\mathrm{b}}$ & $32.93 \pm 0.66^{\mathrm{ab}}$ & $34.41 \pm 0.63^{\mathrm{a}}$ & $34.09 \pm 0.37^{\mathrm{a}}$ & $* * *$ \\
\hline Yolk index\% & $45.32 \pm 0.52^{\mathrm{a}}$ & $41.91 \pm 0.59^{\mathrm{b}}$ & $43.57 \pm 0.57^{\mathrm{b}}$ & $38.98 \pm 0.66^{\mathrm{c}}$ & $* * *$ \\
\hline Yolk color & $4.93 \pm 0.13^{\mathrm{c}}$ & $6.10 \pm 0.13^{\mathrm{a}}$ & $5.80 \pm 0.01^{\mathrm{ab}}$ & $5.62 \pm 014^{\mathrm{b}}$ & $* * *$ \\
\hline Shell \% & $9.68 \pm 0.15$ & $9.47 \pm 0.11$ & $9.63 \pm 0.12$ & $9.29 \pm 0.12$ & NS \\
\hline Shell thickness(mm) & $30.85 \pm 0.65^{\mathrm{c}}$ & $33.86 \pm 0.5^{\mathrm{b}}$ & $32.84 \pm 0.5^{\mathrm{b}}$ & $35.57 \pm 0.51^{\mathrm{a}}$ & $* * *$ \\
\hline
\end{tabular}

Means in the same row with different letters are significantly different $(\mathrm{p} \leq 0.05)$ where,NS ......Non-significant - * $=(\mathrm{p} \leq 0.05)-* *(\mathrm{p} \leq 0.01)-* * *(\mathrm{p} \leq 0.0001)$.

Table 5: Effect of duck age on egg hatchability traits at 4 different ages:

\begin{tabular}{|l|c|c|c|c|c|}
\hline & 24wk old & 32wk old & 40wk old & 48 wk old & significance \\
\hline Fertility\% & $81.5 \pm 1.4^{\mathrm{b}}$ & $89.5 \pm 1.4^{\mathrm{a}}$ & $91.3 \pm 1.7^{\mathrm{a}}$ & $90.8 \pm 1.03$ & $* *$ \\
\hline Early embryonic mortality\% & $19.5 \pm 0.5^{\mathrm{a}}$ & $11.8 \pm 0.5^{\mathrm{b}}$ & $10.7 \pm 0.5^{\mathrm{bc}}$ & $9.8 \pm 0.5^{\mathrm{c}}$ & $* * *$ \\
\hline Late embryonic mortality \% & $6.7 \pm 0.53^{\mathrm{b}}$ & $10.4 \pm 0.53^{\mathrm{a}}$ & $7.5^{\mathrm{b}} 0.53 \mathrm{~b}$ & $6.0 \pm 0.53^{\mathrm{b}}$ & $* * *$ \\
\hline Pip dead \% & $4.4 \pm 0.37^{\mathrm{b}}$ & $9.5 \pm 0.37^{\mathrm{a}}$ & $6.9^{\mathrm{b}} 0.37 \mathrm{~b}$ & $9.7 \pm 0.37^{\mathrm{a}}$ & $* * *$ \\
\hline Total embryonic mortality\% & $30.6 \pm 0.38^{\mathrm{a}}$ & $31.7 \pm 0.38^{\mathrm{a}}$ & $25.1 \pm 0.38 \mathrm{~b}$ & $25.5 \pm 0.38^{\mathrm{b}}$ & $* * *$ \\
\hline Hatchability of total egg \% & $69.0 \pm 0.92$ & $71.3 \pm 2.07$ & $76.6 \pm 1.73$ & $73.8 \pm 2.85$ & NS \\
\hline Duckling weight at hatch $(\mathrm{g})$ & $41.7 \pm 1.09^{\mathrm{b}}$ & $46.3 \pm 1.44^{\mathrm{a}}$ & $47.9 \pm 0.55 \mathrm{a}$ & $47.3 \pm 0.83^{\mathrm{a}}$ & $*$ \\
\hline
\end{tabular}

Means in the same row with different letters are significantly different $(\mathrm{p} \leq 0.05)$ where, NS .....Non-significant - * $=(\mathrm{p} \leq 0.05)-* *(\mathrm{p} \leq 0.01)-* * *(\mathrm{p} \leq 0.0001)$. 
Table 6: Effect of duck age on BWT, BWG, F.C and FCR of young duckling:

\begin{tabular}{|c|c|c|c|c|c|}
\hline \multirow{2}{*}{\multicolumn{5}{|c|}{ Duck breeders age }} & \multirow{2}{*}{ Sig. } \\
\cline { 2 - 6 } \multicolumn{2}{|c|}{ (24wks } & 32wks & 40wks & 48wks & \\
\hline 2 BWT & $328.0 \pm 1.16^{\mathrm{a}}$ & $332.7 \pm 6.37^{\mathrm{a}}$ & $318.3 \pm 7.06^{\mathrm{a}}$ & $305.0 \pm 5.13^{\mathrm{b}}$ & $*$ \\
\hline $4 \mathrm{wks}$ & $925.3 \pm 2.91^{\mathrm{b}}$ & $1060 \pm 70.3^{\mathrm{a}}$ & $707.0 \pm 5.55^{\mathrm{c}}$ & $905.7 \pm 10.8^{\mathrm{b}}$ & $* * *$ \\
\hline $6 \mathrm{wks}$ & $1550.0 \pm 5.78^{\mathrm{b}}$ & $1678.0 \pm 47.7^{\mathrm{a}}$ & $1335.0 \pm 38.7^{\mathrm{c}}$ & $1520.0 \pm 23.1^{\mathrm{b}}$ & $* * *$ \\
\hline $8 \mathrm{wks}$ & $2000.0 \pm 57.8^{\mathrm{a}}$ & $2077.0 \pm 67.5^{\mathrm{a}}$ & $1710.0 \pm 30.2^{\mathrm{b}}$ & $1747.0 \pm 12.0^{\mathrm{b}}$ & $* *$ \\
\hline $10 \mathrm{wks}$ & $2400.0 \pm 57.8^{\mathrm{a}}$ & $2517.0 \pm 88.3^{\mathrm{a}}$ & $1975.0 \pm 62.9^{\mathrm{b}}$ & $1960.0 \pm 5.8^{\mathrm{b}}$ & $* * *$ \\
\hline
\end{tabular}

\section{BWG}

\begin{tabular}{|c|c|c|c|c|c|}
\hline $0-2$ wks & $286.0 \pm 1.48^{\mathrm{a}}$ & $286.0 \pm 6.8^{\mathrm{a}}$ & $270.7 \pm 7.7^{\mathrm{ab}}$ & $258.0 \pm 6.01^{\mathrm{b}}$ & $*$ \\
\hline $2-4 \mathrm{wks}$ & $597.3 \pm 2.67^{\mathrm{b}}$ & $727.3 \pm 67.4^{\mathrm{a}}$ & $388.3 \pm 0.87^{\mathrm{c}}$ & $601.0 \pm 5.8^{\mathrm{b}}$ & $* * *$ \\
\hline $4-6 \mathrm{wks}$ & $625.0 \pm 2.91$ & $618.3 \pm 80.9$ & $628.3 \pm 33.4$ & $614.3 \pm 12.5$ & NS \\
\hline $6-8 \mathrm{wks}$ & $450.0 \pm 52.0^{\mathrm{a}}$ & $398.3 \pm 21.7^{\mathrm{a}}$ & $375.0 \pm 24.7^{\mathrm{a}}$ & $227.0 \pm 16.7^{\mathrm{b}}$ & $* *$ \\
\hline $8-10 \mathrm{wks}$ & $400.0 \pm 11.0^{\mathrm{a}}$ & $440.0 \pm 55.7^{\mathrm{a}}$ & $265.0 \pm 48.3^{\mathrm{b}}$ & $213.3 \pm 6.7^{\mathrm{b}}$ & $* *$ \\
\hline $0-10 \mathrm{wks}$ & $2358.3 \pm 58.7^{\mathrm{a}}$ & $2470.0 \pm 87.8^{\mathrm{a}}$ & $1927.3 \pm 63.4^{\mathrm{b}}$ & $1913.0 \pm 6.4^{\mathrm{b}}$ & $* * *$ \\
\hline
\end{tabular}

FC

\begin{tabular}{|c|c|c|c|c|c|}
\hline $0-2 \mathrm{wks}$ & $372.3 \pm 9.3^{\mathrm{c}}$ & $453.0 \pm 13.3^{\mathrm{b}}$ & $325.0 \pm 8.4^{\mathrm{d}}$ & $502.0 \pm 8.7^{\mathrm{a}}$ & $* * *$ \\
\hline $2-4 \mathrm{wks}$ & $1322.0 \pm 11.7^{\mathrm{b}}$ & $1432.3 \pm 17.2^{\mathrm{a}}$ & $1134.3 \pm 18.4^{\mathrm{c}}$ & $1520.3 \pm 58.4^{\mathrm{a}}$ & $* * *$ \\
\hline $4-6 \mathrm{wks}$ & $1932.3 \pm 6.8^{\mathrm{c}}$ & $2059.0 \pm 9.9^{\mathrm{b}}$ & $2211.3 \pm 14.5^{\mathrm{a}}$ & $2039.0 \pm 32.7^{\mathrm{b}}$ & $* * *$ \\
\hline 6-8wks & $2031.3 \pm 19.1^{\mathrm{a}}$ & $22032.0 \pm 24.8^{\mathrm{a}}$ & $2126.0 \pm 23.9^{\mathrm{a}}$ & $1113.3 \pm 75.8^{\mathrm{b}}$ & $* * *$ \\
\hline $8-10 \mathrm{wks}$ & $2044.0 \pm 11.1^{\mathrm{a}}$ & $2044.0 \pm 30.6^{\mathrm{a}}$ & $1837.0 \pm 27.3^{\mathrm{b}}$ & $830.0 \pm 30.0^{\mathrm{c}}$ & $* * *$ \\
\hline $0-10 \mathrm{wks}$ & $7702.0 \pm 87.8^{\mathrm{a}}$ & $8020.0 \pm 102.0^{\mathrm{a}}$ & $7633.0 \pm 90.5^{\mathrm{a}}$ & $6004.0 \pm 171.7^{\mathrm{b}}$ & $* * *$ \\
\hline
\end{tabular}

\section{FCR}

\begin{tabular}{|c|c|c|c|c|c|}
\hline $0-2$ wks & $1.30 \pm 0.03^{\mathrm{c}}$ & $1.58 \pm 0.01^{\mathrm{b}}$ & $1.19 \pm 0.01^{\mathrm{d}}$ & $1.95 \pm 0.01^{\mathrm{a}}$ & $* * *$ \\
\hline $2-4 \mathrm{wks}$ & $2.21 \pm 0.01^{\mathrm{c}}$ & $1.99 \pm 0.16^{\mathrm{c}}$ & $2.92 \pm 0.06^{\mathrm{a}}$ & $2.53 \pm 0.08^{\mathrm{b}}$ & $* * *$ \\
\hline $4-6 \mathrm{wks}$ & $3.09 \pm 0.02$ & $3.45 \pm 0.48$ & $3.53 \pm 0.16$ & $3.28 \pm 0.02$ & NS \\
\hline $6-8 \mathrm{wks}$ & $4.63 \pm 0.09^{\mathrm{b}}$ & $5.24 \pm 0.36^{\mathrm{b}}$ & $5.72 \pm 0.41^{\mathrm{b}}$ & $8.53 \pm 0.70^{\mathrm{a}}$ & $* *$ \\
\hline $8-10 \mathrm{wks}$ & $5.11 \pm 0.08^{\mathrm{bc}}$ & $4.76 \pm 0.5^{\mathrm{c}}$ & $7.36 \pm 1.23^{\mathrm{ab}}$ & $8.12 \pm 0.45^{\mathrm{a}}$ & $*$ \\
\hline $0-10 \mathrm{wks}$ & $3.26 \pm 0.04^{\mathrm{b}}$ & $3.25 \pm 0.30^{\mathrm{b}}$ & $3.96 \pm 0.08^{\mathrm{a}}$ & $3.13 \pm 0.01^{\mathrm{b}}$ & $* * *$ \\
\hline
\end{tabular}

Means in the same row with different letters are significantly different $(\mathrm{p} \leq 0.05)$ where,NS ......Non-significant $-*=(\mathrm{p}$ $\leq 0.05)-* *(\mathrm{p} \leq 0.01) . * * *(\mathrm{p} \leq 0.0001)$. 


\section{RESULTS AND DISCUSSION}

Table 3 shows the result of egg number, egg weight $(\mathrm{EW})$, egg mass, egg production rate, feed consumption and feed conversion ratio. Egg number and egg production \% were significantly decreased ( $\mathrm{p} \leq 0.05)$ with advancing duck breeders age. As layer get older they produce larger eggs, but fewer numbers than younger layers do, due to decline in ovulation rate over time. Similar results reported by (Johnston and Gous, (2003) and Rayan et al., (2013). While EW during the three periods (24-32) wks, (32-40) wks and (40-48) wks showed a significant increase ( $p$ $\leq 0.01$ ) as the productive season progress this may be due to increase egg yolk \%. Similar trend was noticed by (Johnston and Gous (2007) and Rayan et al., 2013). However, Egg mass didn't show any significant difference during different periods of production season. This may be attributed to increase of EW with age and decrease of egg numbers. Similar results were reported by (Rayan et al., 2013).

Feed consumption of the breeders was significantly increased $(p \leq 0.01)$ with progress of productive season. This may be due to the need of ducks to obtain more nutrient elements for production of larger eggs. Similar studies were reported by (Singh et al., (2009) and Rayan et al., (2013). Feed conversion to egg of duck breeders during different periods didn't show any significant difference. Although of increase of FC, some studies reported increase of FCR with age (Yasmeen et al., (2008) and Rayan et al., (2013).

Results of (Table 4) shows that EW significantly increased $(p \leq 0.0001)$ with advancing breeder ducks age this might be attributed to significant increase in yolk $\%$.similar results were reported by (ElHanoun, et al., (2012) ; Alsobayel et al.,
(2013) and Stępińska et al., (2017). While, Chung and Lee, (2014) didn't found any significant difference between different ages of laying hens. The egg shape index $\%$ also significantly increased $(p \leq 0.0001) \quad$ with advancing duck age this may be due to increase in egg width or the rate at which duck eggs becomes larger in width is faster than rate of being longer. This result was in contrast to studies of, Tumova and Gous, (2012) and Rayan et al., (2013) which recorded decrease in ESI \%. Others studies of Altan et al., (1995) and Padhi et al., (2013) didn't found any significant difference with advancing bird ages and this may be attributed to difference of birds used in these studies. Albumin percentage significantly decreased $(\mathrm{p} \leq 0.05)$ at 40 and 48 weeks of age this may be due to increase of egg weight in a faster rate than albumin. Similar results reported by (Ulmer-Franco et al., (2010) and Yilmaz- Dikmen et al., (2017).

HU showed a significant decrease $(\mathrm{p} \leq 0.01)$ with advancing ducks age, this may attributed to decrease in albumin height because of ovomucin decreased - albumin protein- the most important component in determining the height of the inner thick albumen (Toussant and Latshaw, 1999). Similar results were reported by (Silversides and Scott, (2001); Tona et al., (2004); Nowaczewski et al., (2010) and Tumova and Gous, (2012).

Unlike albumin \%, yolk percentage significantly increased $(p \leq 0.0001)$ with advancing duck age this may be due to increase the ability of duck to synthesis yolk and yolk precursor's. Similar results were reported by ( Zita et al., (2009); Ulmer- Franco et al., (2010) and Yilmaz Dikmen et al., (2017). However, yolk index in this study significantly decreased $(p \leq 0.0001)$ with age this may be due to decrease in yolk height or increase in yolk diameter similar results were reported by (Zita et al., (2009) and Yilmaz Dikmen et al., 
(2017). However, Padhi et al., (2013) reported a significant difference between different ages without specific trend of decrease or increase. Yolk color in this study showed a significant variation $(p \leq 0.0001)$ throughout the whole period of study. The highest mean value was observed in eggs from 32 wks old breeder. While the lowest mean value was observed at 24 wks old. This may be due it's mainly depend on feed ingredients or there is a probability of feed absorption was greater in 32 wks old breeder. Similar results were reported by (Niranjan et al., (2008) ; Rajkumar et al., (2009) and Pahdi et al., (2013). However, Yilmaz Dikmen et al., (2017) observed increase with age.

Egg shell thickness is important property of egg affect the success of embryonic development in poultry (Balkan et al., 2006). Shell percentage in this study didn't show any significant difference this might be due to shell weight increased with a similar rate of egg weight increase. This result disagrees with other studies of Kokoszynski et al., (2007) and Rajkumar et al., (2009). However, shell thickness was significantly increased $(\mathrm{p} \leq 0.0001)$ with advancing duck breeder age. Similar results were reported by Koneva, (1968) and Pahdi et al., (2013). On the contrary some studies were reported decrease in egg shell thickness with ages (Suk and Park, (2001), El-Hanoun et al., (2012) and Rayan et al., (2013).

Our result obtained in Table 5 indicated that the fertility $\%$ increased $(p \leq 0.01)$. with age without significant difference between ages from $32 \mathrm{wks}, 40 \mathrm{wks}$ and 48 wks old breeders. This may be due to increase ability of breeder to fertilization when compared to early period of laying seasons (24wks). Similar results were reported by Ulmer-Franco et al., (2010) and Stępińska et al., (2017) who observed that the lowest fertilization rate was in week 2 of laying season. However, several studies reported that decrease in fertility $\%$ as bird aged (Almarshade, (2011), El-Safty, (2012); Awad and Abd El-Halim, (2014) and Iqbal et al., (2014). This difference may attributed to the fertility of eggs is affected by factors originating from the hen such as her ability to mate successfully, to store sperm, to ovulate an egg cell or to produce a suitable environment for the formation and development of the embryo(Brillard, 2003).

Result of this study revealed that total embryonic mortality significantly decreased with advancing duck age this may be due to significant increase of early embryonic mortality and late embryonic mortality in eggs from 24 and 32 wk old ducks although they reported lower percent of pip dead. This may be due to lower yolk proportion when compared with embryo from ducks aged 40, 48 wk old .Although percent of pip dead increased in older ducks which may be due to increase in shell thickness. Similar results were reported by (Suarez et al., (1997) and Rogue and Soares, (1994) who reported increase in early mortality in younger flock. Also El-Hanoun et al ., , (2012) found that embryonic deaths were higher for the young flock duck during (0-24) day of incubation. On the contrary some studies reported increase in embryonic mortality with advancing bird age (Reis et al., (1997); Elibol and Brake, (2006); El-Safty, (2012) and Mitrovic et al., (2012). However, some studies did not observe any significant difference between different ages (UlmerFranco et al., (2010) and Awad and Abd ElHalim, (2014).

Hatchability \% of total egg in this study didn't show any significant difference, although they are numerically lower in eggs from 24wks old breeder when compared to older breeder, this difference may be attributed to low fertility and higher early embryonic mortality in eggs from 24 wks old. Similar results were reported by Ulmer-Franco et al., 
(2010);Gulhanone et al., (2012) and Othman et al., (2014). On the contrary, some studies reported increase of hatchability with age (Rogue and Soares, (1994); Braun et al., (2002) and El-Hanoun et al., (2012). While, others studies reported decrease of hatchability $\%$ with ages (Abudabos, (2010); El-Safty, (2012); Awad and Abd El-Halim, (2014) and Iqbal et al., (2014). The difference may attributed to different birds and ages used in these studies and hatching of duck eggs has been more difficult than that of chicken eggs because of the reported characteristics of large size, thick eggshells, and high numbers of pores (Changkang et al., 1999).

Duckling weight at hatch were significantly increased $(\mathrm{p} \leq 0.05)$ with age without significant difference between 32, 40 and 48 wks old breeders, this difference may be due to increase of egg weight in this study with duck age. Eggs from older flocks are larger in size and the embryos used yolk nutrients for growth more effectively than those from young parents. In addition, breeders become more efficient in depositing essential embryonic nutrients with increasing parental age. Similar results reported by (Silversides et al., (2006); Alsoybal et al., (2013) and Iqbal et al., (2014). However, some studies didn't notice any significant difference of one day old chicks weight between different ages (Trehan and Bajwa (2001), Braun et al., (2002) and Awad and Abd El-Halim (2014). This difference may be related to different birds and ages of these studies.

Table 6: shows live body weight of young duckling from 1 day old until 10 wks old shows often significant increase in duckling from young breeders (24 and 32) wks old than older breeders (40 and 48) wks. Although weight of young duckling at hatch was higher in older breeders, but the final BWT (10) wks old was higher in young duckling from young breeders (24 and 32) wks which indicate chick weight not affair predictor for final body weight. Old breeder flocks produce a greater number of heavier chicks as a result of increased egg weight (Suarez et al., 1997). However, the percentage of chicks was reported to be higher in older (45-wks) than in younger (35-wks) flocks (Tona et al., 2004). Similar trend observed by (Shanawany, (1987) and Applegate et al., (1999). However for others, this has not been the case (Proudfoot and Hulan, (1981) ; Sklan et al., (2003) and Ulmer-Franco et al., (2010) they demonstrated that chick weight could be an accurate predictor of final BW .

BWG through (0-10) wks old significantly increased in young duckling from young breeders (24 and 32) wks when compared to young duckling from older breeders this increase corresponding to BWT increase and may be attributed to increase of feed consumption of young duckling from younger breeders. On contrast, results of Shanawany, (1987); Braun et al., (2002) and El-Hanoun et al., (2012 showed a positive trend between duckling growth and parental age of ducks.

Feed consumption of young duckling through (0-10) wks old showed a significant decrease with advancing age, but this may be attributed to raising young duckling from older breeder at summer season in Egypt un- like young duckling from younger breeders. On the contrary, several studies reported that the increase of FC with advancing flock age (Braun et al., (2002) and El-Hanoun et al., (2012). However, Applegate et al., (1999) didn't observe any significant difference of FC. FCR of young duckling through (0-10) wks old significantly increased with advancing age, this may be attributed to decrease of feed consumption. However, Applegate et al., (1999) and El-Hanoun et al., (2012) did not find any significant difference FCR between chicks from different ages. 


\section{REFERENCE}

Abudabos, A. (2010): The effect of broiler breeder strain and parent flock age on hatchability and fertile hatchability. Int. J. Poult Sci. ,9(3) ,231-235.

Abu -Tabeekh, M. A. S. (2011): Evaluation of some external and internal egg quality traits of quails reared in Basrah city. Bas. J. Vet. Res. 10, 78-84.

Akyurek, H. and Okur., A.A. (2009): Effect of storage time, temperature and hen age on egg quality in free-range layer hens. J. Anim. Vet. Adv., 8, 19531958.

ALmarshade, A. M. (2011): Effect of breed, age and storage period on fertility and hatchability of commercial breeders' hatching eggs raised under local conditions. M.Sc. Thesis King Saud University.

Alsobayel, A.A., Almarshade, M.A. and Albadry, M.A. (2013): Effect of breed, age and storage period on egg weight, egg weight loss and chick weight of commercial broiler breeders raised in Saudi Arabia. J .Saudi Soc. Agric Sci.12, 53-57.

Altan, O., Oguz, I. and Settar, P. (1995): Effect of egg weight and specific gravity on hatchability and chick weight in Japanese quail. J. Agric. For. 19, 219-222.

Applegate, T. J., Ladwig, E., Weissert, L. and Lilburn, M. S. (1999): Effect of Hen Age on Intestinal Development and Glucose Tolerance of the Pekin Duckling. Poult. Sci., 78, 14851492.
Awad, A. L. and Abd El-Halim and H.A. H. (2014): Some hatching traits of Sinai chicken eggs as affected by flock age, dietary ascorbic acid supplementation and egg storage period under Egyptian conditions. Egypt. Poult. Sci .(34) (IV), 959-978.

Awad, A.L. (2013): Field study on hatching traits of duck eggs under Egyptian environmental conditions. Egypt. Poult. Sci. J., 33, 849-863.

Balkan, M., Karakas, R. and Biricik, M. (2006): Changes in eggshell thickness, shell conductance and pore density during incubation in the Peking duck (Anas platyrhynchosf. dom.). Ornis Fenn ., 83,117-123.

Braun, C.M., Neuman, S., Hester, P.Y. and Latour, M.A. (2002): Breeder age alters offspring performance in the Pekin Duck. J. Appl. Poult. Res., 11, 270-274.

Brillard, J.P. (2003): Practical aspects of fertility in poultry. World's Poult. Sci. J., 59,441-446.

Carter, T. C. (1968): The hen egg. A mathematical model with three parameters. Br. Poult. Sci, 9, 165-171.

Changkang, W., Ang, L. and Guangying, W. (1999): Effects of the quantitative characters of hatching eggs on hatchability in Muscovy duck.1st World Waterfowl Con '.December 1-4, Taichung, Taiwan ., 188-192 in Proc.

Chung, S .H. and Lee, K. W. (2014): Effect of hen age, storage duration and temperature on egg quality in laying hens. International journal of poultry science; 13(11), 634-636.

Duncan, D.B. (1955): Multiple range and multiple F tests. Biometrics, 11, 1-42. 
El-Hanoun, A. M., Rizk, R. E. , Shahein, , E. H. A., Hassan N. S. and Brake, J . (2012): Effect of incubation humidity and flock age on hatchability traits and post hatch growth in Pekin ducks. Poult Sci., 91, 2390-2397.

Elibol, O. and Brake J. (2006): Effect of flock age, cessation of egg turning, and turning frequency through the second week of incubation on hatchability of broiler hatching eggs. Poultry Sci., 85, 1498-1501

El-Safty, S.A. (2012): Influence of genotype and age of egg-type breeders on some hatching traits. Egypt Poult Sci., $32,711-724$.

El-Sheikh, T. M., Abdel-Kareem, A.A.A. and Youns, S. (2014): Egg quality traits and shell microbial contaminations in two commercial layer strains affected by flock age and storage period. Conference: 7th International Poultry Conference - Ain Sukhna, Red Sea - Egypt

Feed Composition Tables for Animals and Poultry Feedstuffs Used in Egypt. (2001): Technical Bulletin No., 1, Central Lab. For Food and Feeds (CLFF) Ministry of Agric. Res. Cent. Egypt.

Gallo, R., Veronico, M., Nacucchi, O., Tafaro, E., Barile, P., Nicastro, F. and Zeeza, L.,(2005): Effects of vitamin E/ PUFA's and dietary inorganic Selenium on quality of broiler breeder males semen. Ital. J. Anim. Sci., 4 (2), 521.

Gualhanone, A., Furlan, R.L., FernandezAlarcon, M.F. and Macari M. (2012): Effect of breeder age on eggshell thickness, surface temperature, hatchability and chick weigh .Rev. Bras. Cienc. Avic.( Brazilian Journal of Poultry Science), 14(1),9-14.
Haugh, R.R. (1937): The Haugh Unit for measuring egg quality. US Poultry Mag. 43,552-573.

Iqbal, J., Khan, S,H., Mukhtar, N., Ahmed ,T. and Pasha, R.A. (2014): Effects of egg size (weight) and age on hatching performance and chick quality of broiler breeder, Journal of Applied Animal Research, 44(1), 54-64.

Johnston, S. A. and Gous, R.M. (2003): An improved mathematical model of the ovulatory cycle of the laying hen. Br. Poult. Sci., 44,752-760.

Johnston, S.A. and Gous, R.M. (2007): Modeling the changes in the proportions of the egg components during a laying cycle. Br. Poult. Sci., 48, 347-353.

Khan, M .K .I, Ali, A. and Bhuiyan, A .K. F .H. (1999) : Economic traits of Deshi males with Isa brown females under farm and rural conditions .Bang. J. Anim. Sci., 28, 9.

Kokoszyński, D., Bernacki, Z. and Korytkowska, H. (2007): Egg shell and egg content traits in Pekin duck eggs from the P44 reserve flock raised in Poland. J. Cent. Eur. Agric., 8, 9-16.

Koneva, A. (1968): Relationship of morphological traits of turkey eggs with hatching of chicks. Ptitsevodstvo, Moscow, Russia, 11, 32-33.

Malik, H.E.E., Sakin, A. I.Y., Elagib, H.A.A., Dousa, B.M. and Elamin, K. M.and (2015): Effect of Egg Weight and egg Shell Thickness on Hatchability and Embryonic Mortality of Cobb Broiler Breeder Eggs. Global Journal of Animal Scientific Research, 3(1), 186-190. 
Mitrovic, S., Pandurevic, T., Stanisic , G., Djekic, V., Djermanovic V. and Jezi, G. (2012) : The effect of the broiler parents age and the period of egg storage on incubation indicators .Third International Scientific Symposium "Agrosym Jahorina "November 15-17, Jahorina, Bosnia and Herzegovina, 559565 .

Niranjan, M., Sharma, R.P., Rajkumar, U., Chatterjee, R.N., Reddy, B.L.N. and Bhattcharya, T. K. (2008): Egg quality traits in chicken varieties developed for backyard poultry farming in India. Livestock Research for Rural Development, 20(12).

Nowaczewski, S., Kontecka, H., Rosiński, A., Koberling, S. and Koronowski, P. (2010): Egg quality of Japanese quail depends on layer age and storage time. Folia Biol. (Kraków), 58, 201-207.

Othman, R. A., Amin, M .R. and Rahman, S. (2014): Effect of egg size, age of hen and storage period on fertility, hatchability, and embryo mortality and chick malformations in eggs of Japanese quail (Coturnix coturnix japonica.J .Agric and vet .sci, 7(1), 101106.

Padhi, M.K., Chatterjee, R.N., Haunshi, S. and Rajkumar, U. (2013): Effect of age on egg quality in chicken. Indian Journal of Poultry Science, 48(1), 122125.

Pirsaraei, Z.A., saki, A.A., Kazemi Fard M. and Saleh, H. (2011): Effect of dietary tallow level on broiler breeder performance and hatching egg characteristics. J. Anim. Vet. Adv., 10,1287-1291.

Proudfoot, F. G. and Hulan, H. W. (1981): The influence of hatching egg size on the subsequent performance of broiler chickens. Poult. Sci. 60,2167-2170.

Rajkumar, U., Sharma, R.P., Rajaravindra, K.S., Niranjan, M., Reddy, B.L.N., Bhattacharya, T.K. and Chatterjee, R.N. (2009): Effect of genotype and age on egg quality traits in naked neck chicken under tropical climate of India. International Journal of Poultry Science, 8, 1151-1155.

Rayan, G.N., Mahrous, M.Y., Galal, A. and El-Attar, A.H. (2013): Study of some productive performance and egg quality traits in two commercials layers strains. Egypt. Poult. Sci. 33 (II), 357-369.

Reis, M.L.H., Gama, L.T. and Soares M.C. (1997): Effects of short storage conditions and broiler breeder age on hatchability, hatching time and chick weights. Poultry Science, 76, 14591466.

Roque, L. and Soares, M.C. (1994): Effects of eggshell quality and broiler breeder age on hatchability. Poult. Sci. 73, $1838-1845$.

SAS institute, (2002): SAS/STAT User's Guide statistics Ver. 9.1; SAS institute Inc., Cary, NC.

Shanawany, M. M. (1987): Hatching weight in relation to egg weight in domestic birds. World's Poult.Sci. J., 43, 107115.

Silversides, F. G. and Scott, T. (2001): Effect of storage and layer age on quality of eggs from two lines of hens. Poult. Sci.80 (8), 1240-1245.

Silversides, F. G., Korver, D. R. and Budgell, K. L. (2006): Effects of strain of layer and age at photo stimulation on egg production, egg quality, and bone strength. Poult. Sci. 85, 1136-1144. 
Singh, R., Cheng, K.M. and Silversides, F.G. (2009): Production performance and egg quality of four strains of laying hens kept in conventional cages and floor pens. Poult. Sci., 88, 256-264.

Singh, R.A. (2001): Poultry Production ‘3rd Edition, Kalyani Publishers New DelhiLudhiana, P: 345.

Sklan, D., Heifetz, S. and Halevy, O. (2003): Heavier chicks at hatch improves marketing body weight by enhancing skeletal muscle growth. Poult. Sci., 82, 1778-1786.

Stępińska, M., Mróz, E., Krawczyk, M., Otowski1, K. and Górska, A. (2017): Effect of hen age and storage time on egg weight loss and hatchability results in turkeys. Ann. Anim. Sci., 17, (2), 447-462.

Suarez, M.E., Wilson, H.R., Mather, F.B., Wilcox, C.J. and Mcpherson, B.N. (1997): Effect of strain and age of the broiler breeder female on incubation time and chick weight. Poultry Science, 76,1029-1036.

Suk, Y.O. and Park, C. (2001): Effect of breed and age of hen on the yolk to albumen ratio in two different genetic stocks. Poultry Science, 80: 855-858.

Tona, K., Onagbesan, O., De Ketelaere, B., Decuypere, E. and Bruggeman, $V$. (2004): Effects of age of broiler breeders and egg storage on egg quality, hatchability, chick quality, chick weight and chick post hatch growth to fortytwo days. J Appl Poult Res. 13, 10-18.

Toussant, M. J. and Latshaw, J. D. (1999): Ovomucin content and composition in chicken eggs with different interior quality. J Sci Food Agric., 79 (12), 1666 -1670 .
Trehan, P.K. and Bajwa, I.S. (2001): Effect of hatching egg weight on chick weight and Juvenile growth in meat-type chickens. SARAS J. Livestock Poultry Prod. 17 (3/4), 78-80.

Tumova, E. and Gous, R.M. (2012): Interaction of hen production type, age and temperature on laying pattern and egg quality. Poult.Sci, 91, 1269-1275.

Tyler, C. (1961): Shell strength: Its measurement and its relationship to other factors. Br. Poult. Sci. 16, 131143.

Ulmer-Franco, A.M. , Cherian, G. , Quezada, N ., Fasenko , G.M. and McMullen , L.M. (2012):Hatching egg and newly hatched chick yolk sac total IgY content at 3 broiler breeder flock ages Poultry Science; $91,758-764$.

Ulmer-Franco, A.M., Fasenko, G.M. and O'Dea Christopher, E. E.( 2010): Hatching egg characteristics, chick quality, and broiler performance at 2 breeder flock ages and from 3 egg weights. Poult.Sci. 89, 2735-2742.

Yasmeen, F., Mahmood, S., Hassan, M., Akhtar, N. and Yaseen, M. (2008): Comparative productive performance and egg characteristics of pullets and spent layers. Pakistan Vet. J., 28(1): 58.

Yilmaz- Dikmn, B., İpek, A., Ü Şahan, Ü. A., Sozcu, A. and Cbaycan, S. C. (2017): Impact of different housing systems and age of layers on egg quality characteristics. Turk .J Vet Anim Sci., 41, 77-84.

Zita, L., Tumova, E. and Štolc, L. (2009): Effects of Genotype, Age and Their Interaction on Egg Quality in BrownEgg Laying Hens. ACTA VET. BRNO, 78, 85-91. 


\title{
الملخص العربي

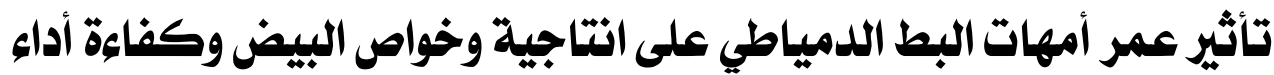 الكتاكيت حديثي الفقس علئس
}

\author{
منى مصطفي الفريب' - بيل أبو هيكل سيد أحمد' - يوسف يحيب عوض الصعيدي' - عبد الفنى محمد الشحات' \\ قسم الفسيولوجيا ـ كليه الطب البيطري - جامعه المنصورة'

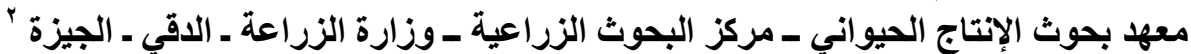

تم اجراء هذه الدراسة لمعرفة تأثثير عمر أمهات البط الدمياطي على بعض الصفات الانتاجية وخواص البيض وكفـاءه أداء الكتاكيت .وقد تم دراسـة كل من(عدد البيض ،وزن البيض ،كتلة البيض، نسبة انتاج البيض ،معدل

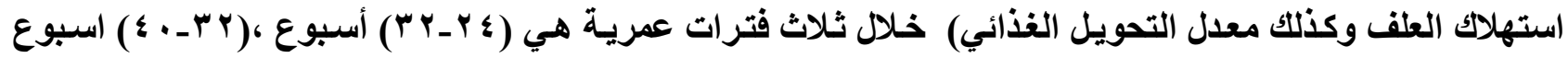

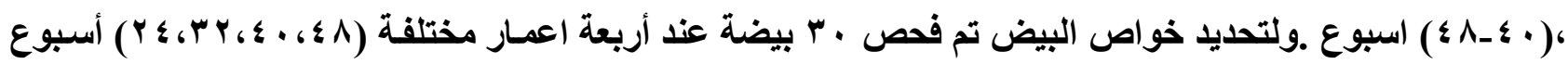
وقياس كل من (وزن البيض ،مؤشر شكل البيضة، نسبة و سمك القشرة، نسبة الزلال ووحدات Haugh نسبة المـح ،مؤشر جودة المح و درجة لون المح .ولتحديد خواص فقس البيض تم الخـال عدد 1 ـ ـب بيضة عند نفس الاعمـار بمعدل ؛ ـ ه بيضة لكل عمر بعد الفقس تم تربية • ب كتكوت من كل مجموعةـ عمر يوم واحدـ لمدة ـ 1 أسابيع وقد تم تسجيل كل من (الوزن- الوزن المكتسب ،معدل استهلاك العلف ومعدل التحويل الغذائي) كل أسبوعين. وقد أظهرت النتائج الاتي: وجود نقص معنوي في نسبة انتاج وعدد البيض مع تقدم عمر أمهات البط بينمـا حدثت زيادة معنوية في وزن البيض خلال الثلاث فترات. ولم توجد أى فروق معنوية في كتلة البيض أو معدل التحويل الغذائي خلال الفترات العمرية المختلفة. بعض خواص البيض (وزن البيضة مؤشر شكل البيضة نسبة المـح وسمك القشرة) أظهرت زيادة معنوية مع تقدم عمر أمهات البط بينما لوحظ نقص معنوي مع تقدم العمر في نسبة الزلال لـم يكن هناك أي فروق معنوية في نسبة القشرة بين الأعمـار المختلفة وأظهرت وحدات Haugh ومؤشر جودة المـح انخفاضا معنويا مع تقام العمر .أما نسبه خصوبة البيض فشهدت زيادة معنوية على العكس من معدل الوفيـات الأولية

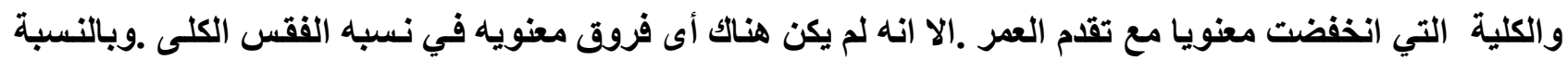
لأداع كتاكيت فقد لوحظ زيادة ف الوزن الأولى للكتكوت مع تقدم العمر ولكن ذلك لم ينعكس على الوزن النهائي او الوزن المكتسب اللذان انخفضا مع تقدم العمر ـوقد لوحظ أعلى معدل لاستهلاك العلف في الامهات عمر ^ ؛ أسبوع بينما سجل اقل معدل للتحويل الغذائي في الامهات عمر ، ؛ أسبوع. مما سبق في هذه الدراسـة يتضح أن عمر أمهات البط كان لله تأثير واضح على بعض صفات إنتاج البيض وخواص البيض والى حد ما أداء الكتاكيت وبالرغم من ذلك لا يمكن تجاهل عامل التغير في درجات الحرار ة. 